\title{
Rapid response to the earthquake emergency of May 2012 in the Po Plain, northern Italy
}

Milena Moretti ${ }^{1, \star}$, Luigi Abruzzese ${ }^{1}$, Nasser Abu Zeid ${ }^{2}$, Paolo Augliera ${ }^{1}$, Riccardo M. Azzara ${ }^{1}$, Carla Barnaba ${ }^{3}$, Lucilla Benedetti ${ }^{4}$, Andrea Bono ${ }^{1}$, Paola Bordoni ${ }^{1}$, Tobias Boxberger ${ }^{5}$, Augusto Bucci ${ }^{1}$, Stefano Cacciaguerra ${ }^{1}$, Marco Calò ${ }^{6}$, Fabrizio Cara ${ }^{1}$, Simona Carannante ${ }^{1}$, Vincenzo Cardinale ${ }^{1}$, Angelo Castagnozzi ${ }^{1}$, Marco Cattaneo ${ }^{1}$, Adriano Cavaliere ${ }^{1}$, Gianpaolo Cecere ${ }^{1}$, Claudio Chiarabba ${ }^{1}$, Lauro Chiaraluce $^{1}$, Maria Grazia Ciaccio ${ }^{1}$, Rocco Cogliano ${ }^{1}$, Gianfranco Colasanti ${ }^{1}$, Marco Colasanti ${ }^{1}$, Cécile Cornou $^{7}$, Françoise Courboulex ${ }^{8}$, Fabio Criscuoli ${ }^{1}$, Giovanna Cultrera ${ }^{1}$, Ezio D'Alema ${ }^{1}$, Ciriaco D'Ambrosio ${ }^{1}$, Stefania Danesi ${ }^{1}$, Pasquale De Gori ${ }^{1}$, Alberto Delladio ${ }^{1}$, Giovanni De Luca ${ }^{1}$, Martina Demartin ${ }^{1}$, Giuseppe Di Giulio ${ }^{1}$, Catherine Dorbath ${ }^{9}$, Emanuela Ercolani ${ }^{1}$, Licia Faenza ${ }^{1}$, Luigi Falco ${ }^{1}$, Andrea Fiaschi ${ }^{10}$, Pietro Ficeli ${ }^{1}$, Antonio Fodarella ${ }^{1}$, Diego Franceschi ${ }^{1}$, Gianlorenzo Franceschina ${ }^{1}$, Massimo Frapiccini ${ }^{1}$, Michel Frogneux ${ }^{6}$, Lucian Giovani ${ }^{1}$, Aladino Govoni ${ }^{1,3}$, Luigi Improta ${ }^{4}$, Eric Jacques ${ }^{11}$, Chiara Ladina ${ }^{1}$, Philippe Langlaude ${ }^{12}$, Valentino Lauciani ${ }^{1}$, Barbara Lolli ${ }^{1}$, Sara Lovati ${ }^{1}$, Francesco Pio Lucente ${ }^{1}$, Lucia Luzi ${ }^{1}$, Alfonso Mandiello ${ }^{1}$, Carlo Marcocci ${ }^{1}$, Lucia Margheriti ${ }^{1}$, Simone Marzorati ${ }^{1}$, Marco Massa ${ }^{1}$, Salvatore Mazza ${ }^{1}$, Diego Mercerat ${ }^{12}$, Giuliano Milana ${ }^{1}$, Felice Minichiello ${ }^{1}$, Giancarlo Molli ${ }^{13}$, Giancarlo Monachesi ${ }^{1}$, Andrea Morelli ${ }^{1}$, Raffaele Moschillo ${ }^{1}$, Francesca Pacor ${ }^{1}$, Davide Piccinini ${ }^{1}$, Ulderico Piccolini ${ }^{1}$, Maurizio Pignone ${ }^{1}$, Stefano Pintore ${ }^{1}$, Silvia Pondrelli ${ }^{1}$, Enrico Priolo ${ }^{3}$, Stefania Pucillo ${ }^{4}$, Matteo Quintiliani ${ }^{1}$, Gaetano Riccio ${ }^{1}$, Marco Romanelli ${ }^{3}$, Antonio Rovelli ${ }^{1}$, Simone Salimbeni ${ }^{1}$, Laura Sandri ${ }^{1}$, Giulio Selvaggi ${ }^{1}$, Andrea Serratore ${ }^{1}$, Marcello Silvestri ${ }^{1}$, Luisa Valoroso $^{1}$, Jerome Van der Woerd ${ }^{6}$, Gianfranco Vannucci ${ }^{1}$, Lucia Zaccarelli ${ }^{1}$

\footnotetext{
${ }^{1}$ Istituto Nazionale di Geofisica e Vulcanologia, Italy

${ }^{2}$ Università di Ferrara, Dipartimento di Scienze della Terra, Ferrara, Italy

${ }^{3}$ Istituto Nazionale di Oceoanografia e di Geofisica Sperimentale (OGS), Sgonico (Trieste), Italy

${ }^{4}$ Centre Européen de Recherche et d'Enseignement des Géosciences de l'Environnement, UMR7330, CNRS /Aix-Marseille Université, Aix-en-Provence, France

${ }^{5}$ Deutsches GeoForschungsZentrum GFZ, Potsdam, Germany

${ }^{6}$ IPGS-EOST, UMR7516 CNRS/Université de Strasbourg, Strasbourg, France

${ }^{7}$ ISTerre, Université de Grenoble 1, IRD, CNRS, Grenoble, France

${ }^{8}$ Géoazur, Université de Nice Sophia-Antipolis, CNRS, OCA, France

${ }^{9}$ IPGS-EOST, UMR7516 CNRS / Université de Strasbourg, and IRDUR54, Strasbourg, France

${ }^{10}$ Fondazione Prato Ricerche, Prato, Italy

${ }^{11}$ Institut de Physique du Globe de Paris, Paris, France

12 CETE Méditerranée, Laboratoire Régional de Ponts et Chaussées, Nice, France

13 Università di Pisa, Dipartimento di Scienze della Terra, Pisa, Italy
}

\section{Article history}

Received July 24, 2012; accepted September 14, 2012.

Subject classification:

Surveys, measurements and monitoring, Instruments and techniques, Seismological data, Emilia 2012 sequence, Sismiko. 


\section{Introduction}

Rapid-response seismic networks are an important element in the response to seismic crises. They temporarily improve the detection performance of permanent monitoring systems during seismic sequences. The improvement in earthquake detection and location capabilities can be important for decision makers to assess the current situation, and can provide invaluable data for scientific studies related to hazard, tectonics and earthquake physics. Aftershocks and the clustering of the locations of seismic events help to characterize the dimensions of the causative fault. Knowing the number, size and timing of the aftershocks or the clustering seismic events can help in the foreseeing of the characteristics of future seismic sequences in the same tectonic environment.

Instrumental rapid response requires a high degree of preparedness. A mission in response to a magnitude $\left(M_{L}\right) 6$ event with a rupture length of a few tens of kilometers might involve the deployment within hours to days of 30-50 seismic stations in the middle of a disaster area of some hundreds of square kilometers, and the installation of an operational center to help in the logistics and communications. When an earthquake strikes in a populated area, which is almost always the case in Italy, driving the relevant seismic response is more difficult. Temporary station sites are chosen such as to optimize the network geometry for earthquake locations and source study purposes. Stations have to be installed in quiet, but easily reachable, sites, and for real-time data transmission, the sites might need to have optical intervisibility. The operational center can remain in a town if there is one within the damaged area, and it should coordinate the actions of the field teams and provide information to colleagues, the Civil Protection Authorities and the general public. The emergency system should operate as long as the seismic rate remains high; the duration of any mission might also depend on the seismic history of the area involved. This study describes the seismic response following the May 20, 2012, $\mathrm{M}_{\mathrm{L}} 5.9$ earthquake in northern Italy, which included rapid deployment of seismological stations in the field for real-time seismic monitoring purposes, the coordination of further instrumental set-ups according to the spatial evolution of the seismic sequence, and data archiving.

\section{The INGV rapid response system}

Since 1990, the Istituto Nazionale di Geofisica e Vulcanologia (INGV; National Institute of Geophysics and Volcanology) has had an emergency structure ready to face the occurrence of damaging earthquakes. Temporary seismic networks have been usually deployed for $\mathrm{M}_{\mathrm{L}} \geq 5.0$ crustal earthquakes that have occurred in the Italian territory; these have been important monitoring and scientific tools to better understand the last major seismic sequences (e.g., Carlentini in 1990, Umbria-Marche in 1997-1998, Forlì in 2000 and Molise in 2002). In 2008, a new emergency structure was

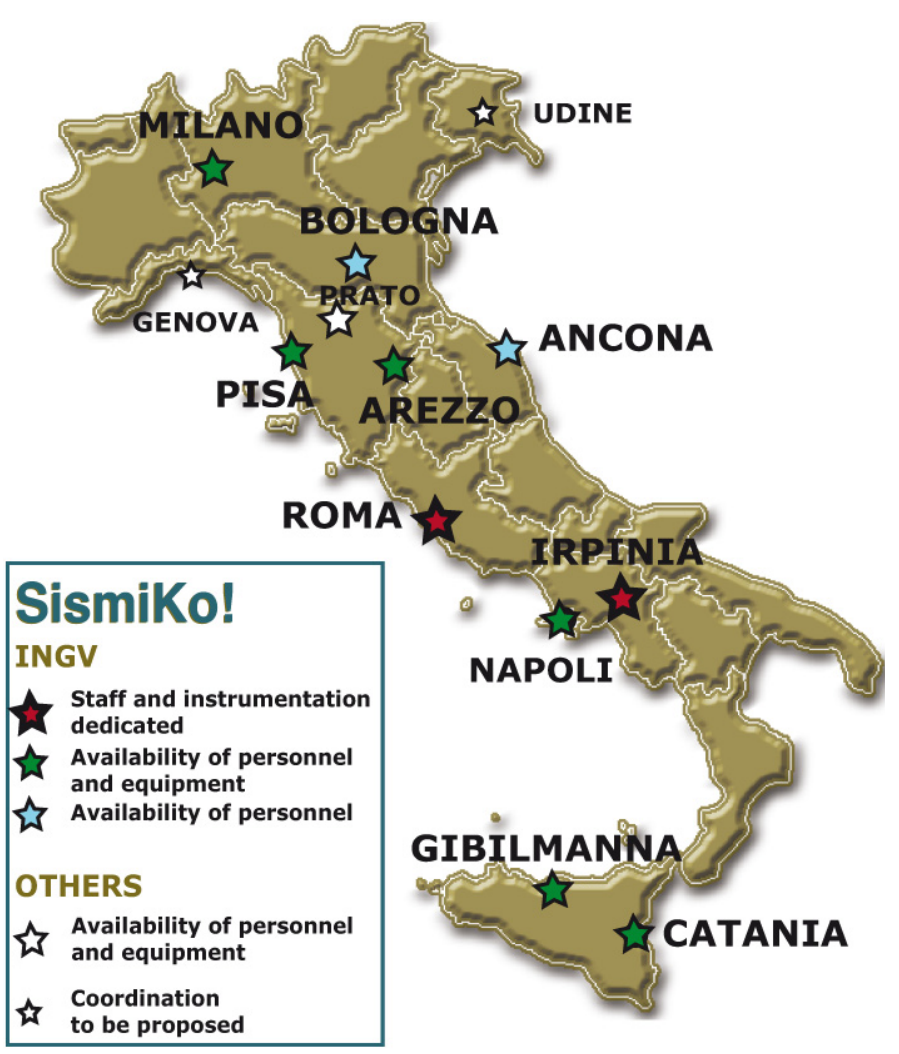

Figure 1. INGV centers in the Italian territory. Differently colored stars, availability of both personnel and instruments or personnel only for emergency network deployments; white stars, other Italian Institutes that generally deploy temporary stations (e.g., Prato Ricerche, OGS and Genova University).

co-founded with the Civil Protection Department (DPC; Dipartimento di Protezione Civile; see 2012-2021 decennial Agreement between the DPC and the INGV; http: / / istituto. ingv.it/1-ingv/progetti/allegati-convenzioni-dpc/accordoquadro-2012-2021). This was tested for the first time during a regional seismic emergency simulation that was organized by the Civil Protection of the Marche Regione. This structure is composed of three operational units: (i) a real-time temporary seismic network; (ii) a stand-alone temporary seismic network; and (iii) the Seismic Emergency Operational Centre (COES; Centro Operativo Emergenza Sismica) [Govoni et al. 2008]. The COES is the INGV facility that is devoted to seismic emergency management in an epicentral area [Moretti et al. 2010a]: it is a mobile office equipped with satellite internet communication that can be rapidly installed in a disaster area. The COES supports the INGV staff operative needs, and helps in the coordination with other national and international Institutes. It cooperates with the DPC by providing updated information 24 hours a day, which contributes to the decision-making stages during an emergency. Furthermore, the COES serves as a reference information center for all of the people involved in the crisis management, and thus provides important practical, and also psychological, support [La Longa and Crescimbene 2010] to the rescuers and to the population affected by an earthquake.

The experience of the L'Aquila earthquake in 2009 
taught us that coordination between national and international Institutes in the deploying of seismic stations is fundamental to optimize material, human and management resources and scientific results [Margheriti et al. 2011, Chiaraluce et al. 2011].

Today the INGV structure for rapid response to seismic emergency [Moretti et al. 2010b] is based on the one that operated during the L'Aquila earthquake, but with an increased number of temporary seismic networks. The different sets of temporary seismic stations (networks) that belong to different INGV centers can either be independently deployed or coordinated into a unique network. This integrated seismic network is composed of: 1 . Real-time stations equipped with both radio-satellite (Re.Mo.Tel.) [Abruzzese et al. 2011] and universal mobile telecommunications system transmission (Re.Mo.-UMTS), which then become part of the National Seismic Network (RSN; Rete Sismico Nazionale) [Amato and Mele 2008]. This ensures substantial improvements in the real-time monitoring systems. 2. Standalone recording stations (Re.Mo.-STANDALONE and EMERSITO) [Bordoni et al. 2012, this volume] that guarantee the acquisition of high resolution data devoted to the improvement of our scientific knowledge (e.g., seismic hazard, seismotectonics, earthquake physics, site response, wave propagation studies).

The INGV seismic stations and the people involved in the emergency deployment are distributed in different centres in the Italian territory (Figure 1: Ancona, Arezzo, Bologna, Catania, Gibilmanna, Irpinia, Milan, Naples, Pisa and Rome). In the last year, an internal INGV project was launched, named as 'Sismiko', to coordinate the activities during these emergencies and to establish common procedures for station deployment, network maintenance and data archiving. After the emergency alarm to all Sismiko participants, the deployment is coordinated by one central office that designs the possible network geometry and assigns the installation sites to the different groups in the field, according to the instrument availability and the achievable group reaction time. Station installation and maintenance can be performed by teams composed of staff coming from different centers, to guarantee knowledge of the area, and of the instruments and their interchangeability. The data are archived in Standard for the Exchange of Earthquake Data (SEED) format, and need to be available to the scientific community as soon as possible (they can be restricted up to 3 years duration for specific projects). In the case of the May-June 2012 Emilia seismic sequence, the Sismiko effort resulted in a much faster reaction than in the past for all of the INGV components, and in an easier management of the intervention.

At the European level, within the framework of the 'Network of European Research Infrastructures for Earthquake Risk Assessment and Mitigation (NERA)' European project, a European Rapid Response Network (ERN) is being developed [Margheriti et al. 2011]. Four European Institutes (INGV, Italy;
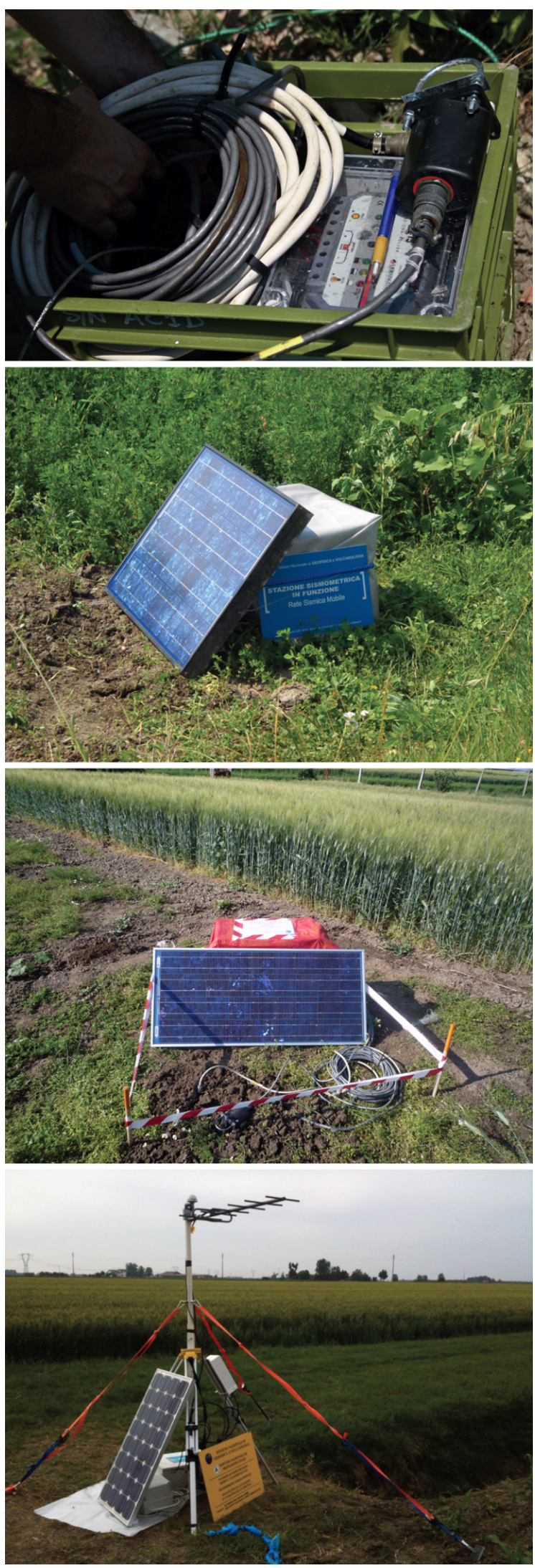

Figure 2. Photographs of the seismic deployments in the Po Plain, showing the standalone recording stations and the stations connected in real-time to the seismic monitoring center in Rome. Top to bottom: the seismic stations (digitizer, GPS, battery and cables) are transported and installed inside a plastic case. The case is covered by a tarpaulin and a sign explains the instrument scope and gives contact information. Most of the stations are powered with solar panels; the sensor is buried inside a plastic bag close to the station. Stations transmitting data in real-time are equipped with antennas. 
GFZ, German Research Centre for Geosciences, Germany; ETH, Eidgenössische Technische Hochschule, Switzerland; CNRS, Centre National de la Recherche Scientifique, France) are combining their efforts under the one umbrella, to set up a common European framework for the coordination of future post-seismic initiatives. This on-going project has facilitated the exchange of information at the European level (http://www.nera-eu.org/content/mm_files/do_798/NERAWP4-Webpage-Update.pdf), and the coordination of station deployment with European colleagues during the May-June 2012 Emilia seismic sequence.

\section{The Emilia seismic sequenceand the rapid response timing}

At 02:03 UTC (04:03 local time) on Sunday, May 20, 2012 , an earthquake of $M_{L} 5.9$ hit northern Italy $\left(44.89^{\circ} \mathrm{N}\right.$, $11.23{ }^{\circ} \mathrm{E}, 6.3 \mathrm{~km}$ in depth) which resulted in casualties and severe damage to the historical buildings and to the economical activities of the region. In the following 72 hours (May 20-22, 2012) the RSN located about 300 events, 68 of which had $\mathrm{M}_{\mathrm{L}} \geq 3.0$ (including 13 events with $\mathrm{M}_{\mathrm{L}} \geq 4.0$ ) (data source: 2005-2012 ISIDe-Italian seismological instrumental and parametric data-base) [Mele et al. 2011]. After few minutes, the mainshock was followed by a $\mathrm{M}_{\mathrm{L}} 5.1$ event, and after a few hours, by a second $M_{L} 5.1$ earthquake (origin time, 13:18 UTC). After the mainshock struck, contact among the different INGV centers started immediately, and early in the morning of May 20, 2012, the first INGV emergency rapid-response group was heading to the meizoseismal area. The first real-time station started operating (i.e., sending real-time data to the INGV monitoring system) at about 10:30 a.m. on May 20, 2012. The INGV groups from Ancona, Arezzo, Bologna, Milan, Irpinia, Pisa and Rome installed 16 seismic stations (eight with real time transmission) within the first 48 hours (Figure 2). The whole meizoseismal area is characterized by the presence of the Po Plain sediments, which did not allow the deploying of the stations on rock outcrops. In the meantime, the INGV group started the coordination with other Italian and foreign Institutes (Prato Ricerche; OGS, Istituto Nazionale di Oceoanografia e di Geofisica Sperimentale; DPC; NERA project participants).

During the first days of the sequence, the rate of seismicity remained high, with more than 60 events per day. On May 29, 2012, at 07:00 UTC, a new large earthquake, of $M_{L} 5.8$, struck the area at the western edge of the ongoing seismic sequence $\left(44.85^{\circ} \mathrm{N}, 11.09^{\circ} \mathrm{E}, 10.2 \mathrm{~km}\right.$ in depth). This was followed by several earthquakes, including $M_{L} 5.2$ and $M_{L} 5.3$ events, at 10:55 UTC and 11:00 UTC, respectively, of May 29, 2012. The emergency seismic network continued to improve under the central coordination of the INGV. As soon as further stations became available, the network was expanded, following the spatial evolution of the seismic sequence (details and timing of the installation are described in Moretti et al. [2012]). When a 5.1 magnitude event occurred on June 3, 2012, at 19:20 UTC, about 70 seismic stations were operating for the emergency (Figure 3), including stations managed by French groups. The 10 real-time stations (Re.Mo.Tel and Re.Mo.-UMTS) integrated into the RSN contributed to the INGV event locations for monitoring purposes. The 15 DPC strong-motion stations made use of the

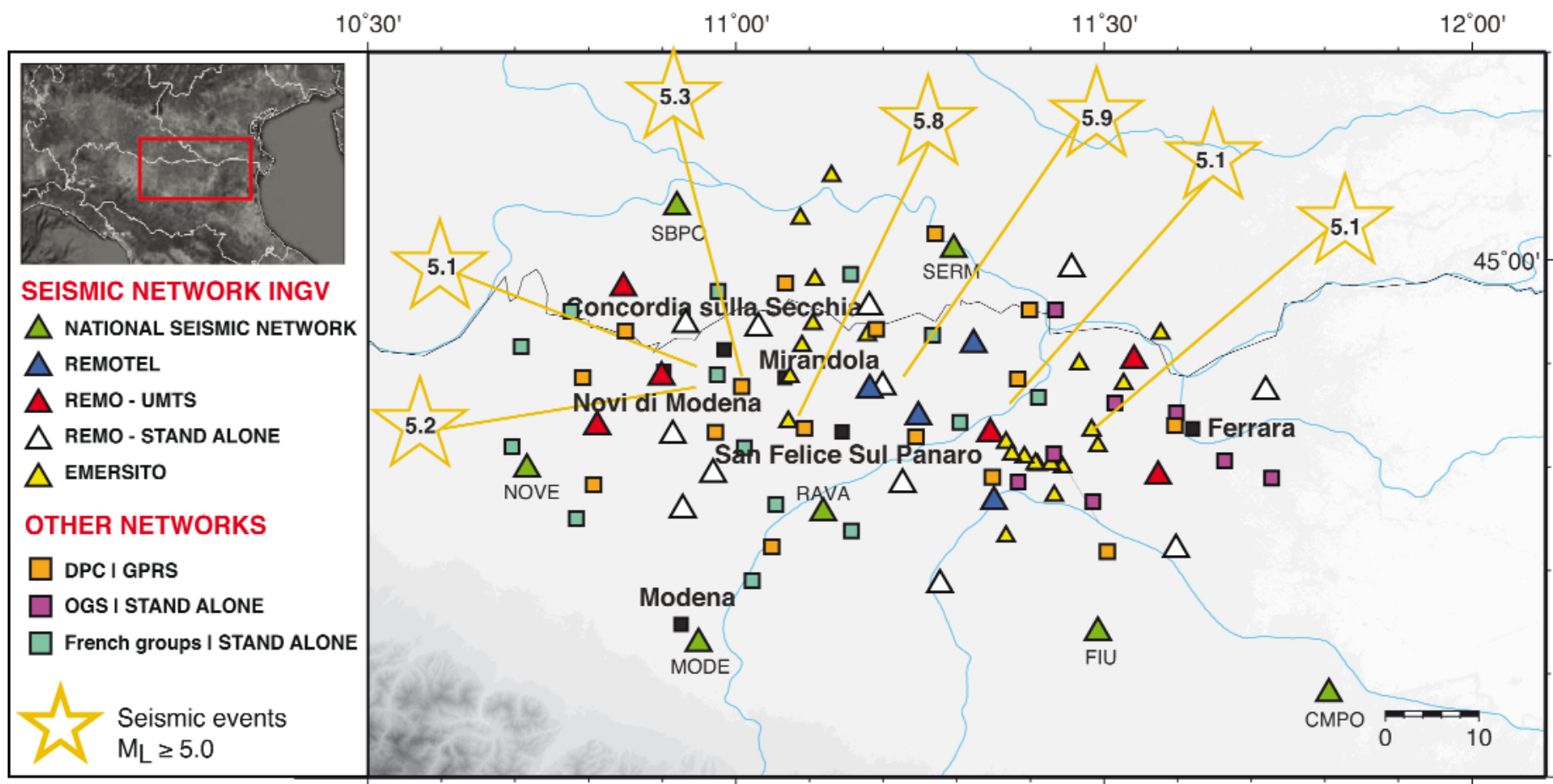

Figure 3. Map of the seismic stations deployed after May 20, 2012. Triangles, INGV permanent (green) and temporary stations; squares, stations from other Institutes; stars, earthquakes with magnitude $>5.0$. 


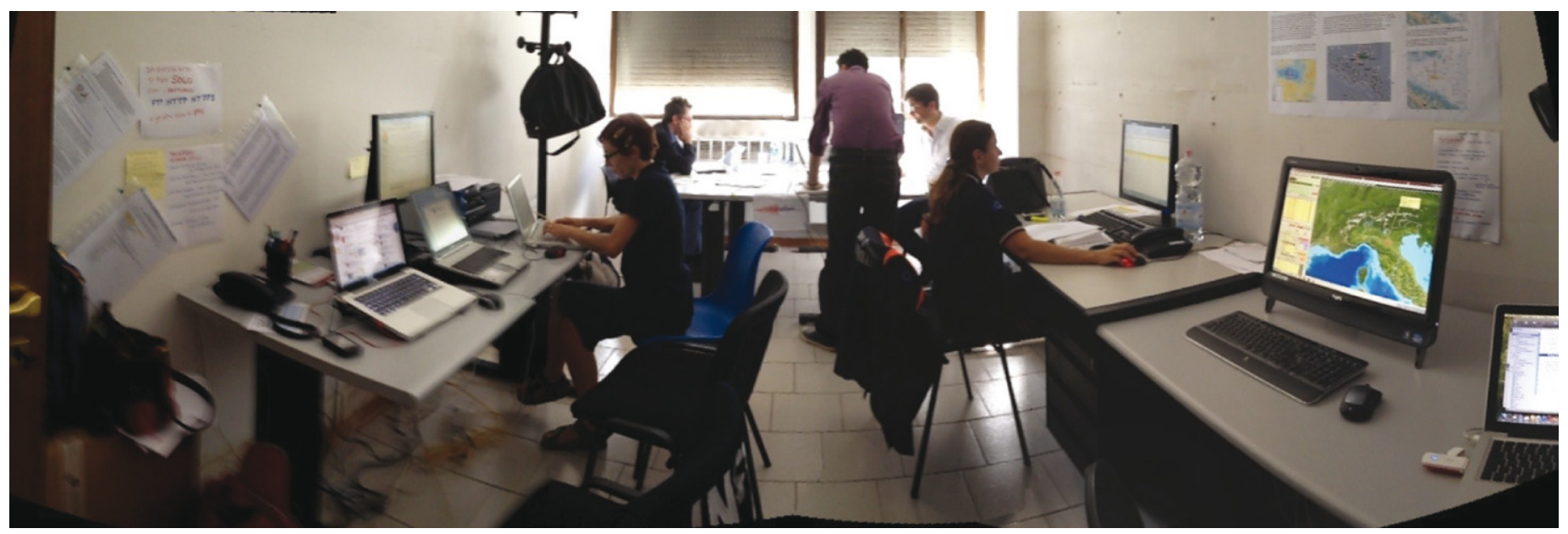

Figure 4. Photograph of the COES room in Bologna.

General Packet Radio Service data transmission to the DPC acquisition center [Zambonelli et al. 2011]. The ca. 50 remaining stations, which were recording as standalone, from the INGV (Re.Mo.-STANDALONE and EMERSITO) and other Institutes (OGS; Università di Ferrara; French IPGSEOST stations coordinated by INSU, Institut National des Sciences de l'Univers/CNRS) will provide excellent datasets for scientific studies.

After this 5.1 magnitude earthquake on June 3, 2012, the seismicity was characterized by a progressive decrease in the seismic rate and seismic moment release (http:/ / ingvterre moti.wordpress.com/category/i-terremoti-della-pianurapadana-emiliana/aggiornamento-sismicita/).

The formal COES was activated at the Agenzia della Protezione Civile Regionale dell'Emilia-Romagna in Bologna relatively late, on June 8,2012 , because the INGV center in Bologna was previously fulfilling the COES tasks. The COES (Figure 4) ensured continuous and direct communication with the DPC officers present in the epicentral area, 24 hours a day, providing formal updates on the seismic sequence twice a day. At the same time, the structure helped in providing education and information services to support the affected populations, and for the Civil Protection operators and rescue volunteers (http: / /ingvterremoti.wordpress.com/ category/informazione/).

The duration of this rapid response mission will depend on the trend of the seismic rate and the seismic moment release, along with information drawn from historical seismic catalogs. The historical seismic catalogs indicate a relatively moderate seismicity in this area, as well as in neighboring

$10^{\circ} 30^{\prime}$

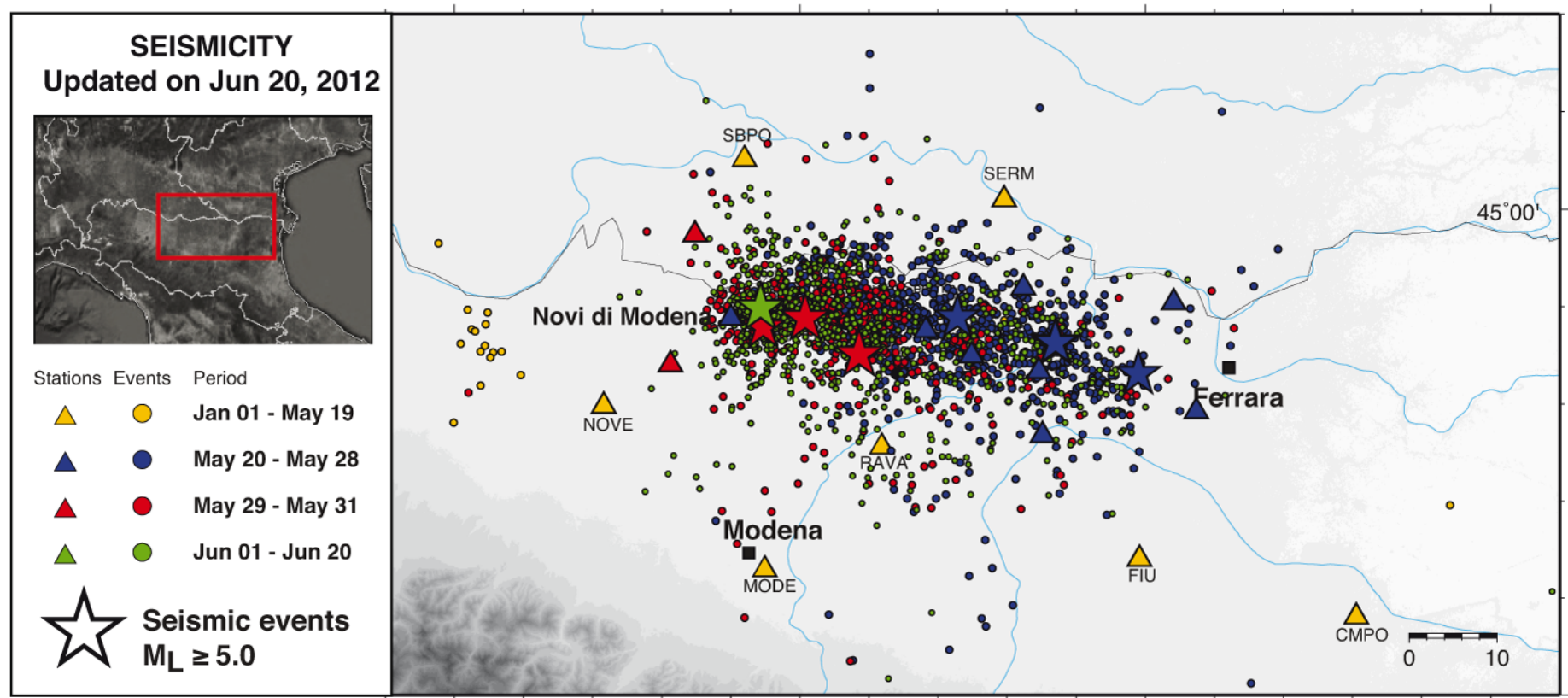

Figure 5. Earthquakes located by the INGV monitoring system for the period January to June, 2012. Black circles, towns and villages; colored triangles, seismic stations; circles and stars, earthquakes with magnitude $>5.0$. Earthquakes and stations are color-coded according to occurrence/deployment time relative to the scale on the legend. 
areas in the Po Plain, which have been characterized by earthquakes with maximal estimated magnitudes close to 5.5 [i.e., Selvaggi et al. 2001]. It is interesting to note that the seismic sequence that struck the city of Ferrara (estimated magnitude of $M_{W}$ 5.5) on November 17, 1570, was a sequence of four strong shocks [DBMI11; Locati et al. 2011]. It was a complex and long sequence, and it including an event on March 17, 1574, that produced damage in Finale Emilia (estimated magnitude of $\mathrm{M}_{\mathrm{W}}$ 4.7), one of villages most damaged by the 2012 seismic sequence.

\section{Data archives and preliminary results}

The INGV temporary network data, as defined in the Sismiko agreement, are being stored within the European Integrated Data Archive (EIDA; http://eida.rm.ingvit/) waveform archive, to make it available to the scientific community [Mazza et al. 2011, Moretti and Govoni 2011, Mazza et al. 2012, this volume]. The continuous data are archived in SEED format and can be requested by the scientific community in SEED or SAC format. Data from the Re.Mo. and Re.Mo.Tel stations (22 stations, named as T0800-T0828) are available on EIDA at the time of writing (July 2012). All of both the real-time and standalone INGV stations are, or are going to be, registered at the International Seismological Centre (ISC; http:/ / www.isc.ac.uk/). Some restrictions on data access will be applied to the EMERSITO network. OGS colleagues will share their continuously recorded data, without restrictions, through the OASIS portal (http:/ / oasis.crs. inogs.it/) [Priolo et al. 2012, this volume]; French colleagues will do the same through the RESIF portal (http:/ / www. resifffr/portal). DPC data consists of triggered events; the two mainshocks are available on the official Department website, and other events recorded within the DPC-Rete Accelerometrica Nazionale (RAN; National Accelerometer Network), with magnitudes $>5.0$ will be released soon.

A first report on the quality control procedures applied to the temporary network data, and to the very preliminary results obtained by an automatic analysis of the continuous waveforms, has been prepared by Marzorati et al. [2012, this volume]. Overall the station operation scores were satisfactory: by the end of June, the real-time stations had contributed to the location of about 2000 earthquakes by the RSN, by providing more than $5000 \mathrm{P}$-wave and more than $4000 \mathrm{~S}$-wave pickings, allowing thus for enhanced completeness and accuracy of the earthquake list distributed by the INGV through ISIDe (Figure 5). Refined magnitude estimations and earthquake location procedures need to take into account that all of the temporary stations were installed on the soft sediments of the Po Plain, an aspect that has not been rigorously dealt with in real-time monitoring due to the obvious lack of time. In Figure 5, the aftershocks located by the real-time INGV monitoring system, and the stations in real-time, are colored according to their temporal evolution; this allows for a comprehensive view of the seismic sequence spatio-temporal evolution and the parallel rapid-response seismic network development. On the whole, the epicenter distribution was elongated about $50 \mathrm{~km}$ in the $\mathrm{E}-\mathrm{W}$ direction, from the town of Ferrara to the village of Novi di Modena. Most of the seismic events and all of those with magnitude $>5.0$ were thrust events [Scognamiglio et al. 2012, Pondrelli et al. 2012, this volume], in agreement with the well-known geological structures buried under the sediments of the Po Plain [Boccaletti et al. 2011] and with the ca. N-S compressional stress regime in the region [Mariucci et al. 1999].

Currently, several research groups are in the process of analyzing the continuous data stored in EIDA [e.g., Marzorati et al. 2012, Scognamiglio et al. 2012; Govoni, personal communication] for the improvement of the locations, the magnitude estimations, and understanding of the seismic sequence.

\section{Conclusions}

Rapid earthquake response is very challenging and requires a high degree of preparedness. The coordination projects launched within Sismiko at a national scale and inside NERA at the European level constitute an important first step towards being prepared. The contacts established in these projects significantly helped the rapidity and coordination of the seismic deployment. The national and European protocols established for data transmission and data archiving have succeeded in improving the real-time monitoring system and the data availability to the scientific community.

Further improvements are foreseen: at least once every year, there will be the organization of a seismic-risk emergency simulation, which will allow enhanced technical and scientific exchange among the groups, to lubricate the communication and coordination skills.

Acknowledgements. We want to thank the many people who contributed to the success of the seismic rapid-response in the earthquake area in Emilia, and all of our colleagues involved in the Sismiko coordination, from the Arezzo, Catania, Gibilmanna, L'Aquila and Naples centers, who are always ready to take part in any new seismic emergency. We are grateful to Elisa Zambonelli and other DPC colleagues for the coordinating of our efforts during the deployment of the seismic stations.

\section{References}

Amato, A., and F.M. Mele (2008). Performance of the INGV National Seismic Network from 1997 to 2007, Annals of Geophysics, 51 (2/3), 417-431.

Abruzzese, L., G. De Luca, M. Cattaneo, G. Cecere, V. Cardinale, A. Castagnozzi, C. D'Ambrosio, A. Delladio, M. Demartin, L. Falco, D. Franceschi, A. Govoni, A. Memmolo, F. Migliari, F. Minichiello, M. Moretti, R. Moschillo, M. Pignone, G. Selvaggi and L. Zarrilli (2011). La Rete Sismica Mobile in Telemetrata Satellitare (Re.Mo.Tel.), Rapporti Tecnici INGV, 177, 32 pp. 
Boccaletti, M., G. Corti and L. Martelli (2011). Recent and active tectonics of the external zone of the northern Apennines (Italy), Int. J. Earth Sci., 100, 1331-1348; doi: 10.1007/ s00531-010-0545-y.

Bordoni, P., R.M. Azzara, F. Cara, R. Cogliano, G. Cultrera, G. Di Giulio, A. Fodarella, G. Milana, S. Pucillo, G. Riccio, A. Rovelli, P. Augliera, L. Luzi, S. Lovati, M. Massa, F. Pacor, R. Puglia and G. Ameri (2012). Preliminary results from EMERSITO, a rapid response network for site-effect studies, Annals of Geophysics, 55 (4); doi:10.4401/ag-6153.

Chiaraluce, L., L. Valoroso, D. Piccinini, R. Di Stefano and P. De Gori (2011). The anatomy of the 2009 L'Aquila normal fault system (central Italy) imaged by high resolution foreshock and aftershock locations, J. Geophys. Res., 116, B12311, doi:10.1029/2011JB008352.

Govoni, A., L. Abruzzese, A. Amato, A. Basili, M. Cattaneo, C. Chiarabba, A. Delladio, G. Monachesi, M. Moretti, G. Selvaggi and E. Boschi (2008). Sequenze sismiche: La nuova struttura di Pronto Intervento dell'Istituto Nazionale di Geofisica e Vulcanologia, $27^{\circ}$ Convegno Nazionale GNGTS, Trieste 6-8 ottobre 2008.

La Longa, F., and M. Crescimbene (2010). La dimensione psicologica del terremoto che ha colpito l'Abruzzo, Report; http: / / www.earth-prints.org/handle/2122/ 5869

Locati, M., R. Camassi and M. Stucchi, eds. (2011). DBMI11, the 2011 version of the Italian Macroseismic Database, Milano, Bologna; http: / / emidius.mi.ingv.it/DBMI11

Margheriti, L., L. Chiaraluce, C. Voisin, G. Cultrera, A. Govoni, M. Moretti, P. Bordoni, L. Luzi, R. Azzara, L. Valoroso, R. Di Stefano, A. Mariscal, L. Improta, F. Pacor, G. Milana, M. Mucciarelli, S. Parolai, A. Amato, C. Chiarabba, P. De Gori, F.P. Lucente, M. Di Bona, M. Pignone, G. Cecere, F. Criscuoli, A. Delladio, V. Lauciani, S. Mazza, G. Di Giulio, F. Cara, P. Augliera, M. Massa, E. D'Alema, S. Marzorati, M. Sobiesiak,, A. Strollo, A.M. Duval, P. Dominique, B. Delouis, A. Paul, S. Husen and G. Selvaggi (2011). Rapid-response seismic networks in Europe: the lesson learned from L'Aquila earthquake emergency, Annals of Geophysics, 54 (4), 392-399, doi: 10.4401/ag-4953.

Mariucci, M.T., A. Amato and P. Montone (1999). Recent tectonic evolution and present stress in the northern Apennines (Italy), Tectonics, 18, 108-118.

Marzorati, S., S. Carannante, M. Cattaneo E. D'Alema M. Frapiccini, C. Ladina, G. Monachesi and D. Spallarossa (2012). Automated control procedures and first results from the temporary seismic monitoring of the 2012 Emilia sequence, Annals of Geophysics, 55 (4); doi:10. 4401 / ag-6116.

Mazza, S., A. Bono, V. Lauciani, C. Marcocci, A. Mandiello, L. Margheriti, F. Mele, M. Moretti, S. Pintore, S., M. Quintiliani, L. Scognamiglio and G. Selvaggi (2011). L'archiviazione e la distribuzione dei dati sismologici del CNT e l'integrazione dei dati della RSM, In: M. Cattaneo and M. Moretti (eds.), Riassunti estesi $1^{\circ}$ Workshop Tecnico 'Monitoraggio sismico del territorio nazionale: stato dell'arte e sviluppo delle reti di monitoraggio sismico', Roma 20, 21 dicembre 2010, Miscellanea INGV, 10, 131-134, ISSN 2039-6651.

Mazza, S., A. Basili, A. Bono, V. Lauciani, A.G. Mandiello, C. Marcocci, F.M. Mele, S. Pintore, M. Quintiliani, L. Scognamiglio and G. Selvaggi (2012). AIDA - Seismic data acquisition, processing, storage and distribution at the National Earthquake Center, INGV, Annals of Geophysics, 55 (4); doi:10.4401/ag-6145.

Mele, F., A. Basili, A. Bono, V. Lauciani, A. Mandiello, C. Marcocci, S. Mazza, S. Pintore, M. Quintiliani, L. Scognamiglio and G. Selvaggi (2011). La base di dati ISIDe: stato attuale e possibili sviluppi, In: M. Cattaneo and M. Moretti (eds.), Riassunti estesi $1^{\circ}$ Workshop Tecnico 'Monitoraggio sismico del territorio nazionale: stato dell'arte e sviluppo delle reti di monitoraggio sismico', Roma 20, 21 dicembre 2010, Miscellanea INGV, 10, 128-130, ISSN 2039-6651.

Moretti, M., A. Govoni, A. Basili, A. Amato, F. Doumaz, S. Vinci and G. Selvaggi (2010a). Progettazione e realizzazione del Centro Operativa Emergenza Sismica (COES), Rapporti Tecnici INGV, 172, 24 pp.

Moretti, M., A. Govoni, G. Colasanti, M. Silvestri, E. Giandomenico, S. Silvestri, F. Criscuoli, L. Giovani, A. Basili, C. Chiarabba and A. Delladio (2010b). La Rete Sismica Mobile del Centro Nazionale Terremoti, Rapporti Tecnici INGV, 137, 66 pp.

Moretti, M., and A. Govoni (2011). La Rete Sismica Mobile del CNT e la Co.Re.Mo, In: M. Cattaneo and M. Moretti (eds.), Riassunti estesi $1^{\circ}$ Workshop Tecnico 'Monitoraggio sismico del territorio nazionale: stato dell'arte e sviluppo delle reti di monitoraggio sismico', Roma 20, 21 dicembre 2010, Miscellanea INGV, 10, 51-54, ISSN 2039-6651.

Moretti, M., et al. (2012). Emergency structure activities perfomed after the Emilia earthquake: report on the first month, Quaderni di Geofisica, INGV, submitted.

Pondrelli, S., S. Salimbeni, P. Perfetti and P. Danecek (2012). Quick regional centroid moment tensor solutions for the Emilia 2012 (northern Italy) seismic sequence, Annals of Geophysics, 55 (4); doi:10.4401/ag-6146.

Priolo, E., M. Romanelli, C. Barnaba, M. Mucciarelli, G. Laurenzano, L. Dall'Olio, N. Abu-Zeid, R. Caputo, G. Santarato, L. Vignola, C .Lizza and P. Di Bartolomeo (2012). The Ferrara thrust earthquakes of May-June 2012: preliminary site response analysis at the sites of the OGS temporary network, Annals of Geophysics, 55 (4); doi:10.4401/ag-6172.

Scognamiglio, L., L. Margheriti, F.M. Mele, E. Tinti, A. Bono, P. De Gori, V. Lauciani, F. P. Lucente, A.G. Mandiello, C. 
Marcocci, S. Mazza, S. Pintore and M. Quintiliani (2012). The 2012 Pianura Padana Emiliana seimic sequence: locations, moment tensors and magnitudes, Annals of Geophysics, 55 (4); doi:10.4401/ag-6159.

Selvaggi, G., F. Ferulano, M. Di Bona, A. Frepoli, R. Azzara, A. Basili, C. Chiarabba, M.G. Ciaccio, F. Di Luccio, F.P. Lucente, L. Margheriti and C. Nostro (2001). The Mw 5.4 Reggio Emilia 1996 earthquake: active compressional tectonics in the Po Plain, Italy, Geophys. J. Int., 144, 1-13.

Zambonelli, E., R. De Nardis, L. Filippi, M. Nicoletti and M. Dolce (2011). Performance of the Italian strong-motion network during the 2009, L'Aquila seismic sequence (central Italy), B. Earthq. Eng., 9, 39-65.

${ }^{\star}$ Corresponding author: Milena Moretti, Istituto Nazionale di Geofisica e Vulcanologia,Centro Nazionale Terremoti, Roma, Italy; email: milena.moretti@ingv.it. 